\title{
The influence of pipe diameter selection on operating costs of heating installation in the context of the anticipated increase in electricity prices
}

\author{
Maciej Knapik ${ }^{1, *}$ \\ ${ }^{1}$ Institute of Thermal Engineering and Air Protection, Faculty of Environmental Engineering, \\ Cracow University of Technology
}

\begin{abstract}
The article presents an analysis of the influence of selection a pipe diameter on the operating costs of a heating installation in the context of the expected increase in electricity charges required to motive the main circulation pump of the installation. As a result of a combination of several factors affecting the Polish energy sector based on coal, energy price increases seem inevitable. Polish government's response to the forecasted increases in charges for electricity is a proposal to introduce subsidies for electricity bills. The article presents the results of the analysis of pipe selection from several standard types, including investment and operating costs, and a comparison of results before and after the increase in electricity charges and including the influence of limescale precipitation on the internal surfaces of pipe walls. The results analyzes show that the increase in charges for electricity affects the selection of the pipe diameter, like the problem of the formation of limescale can significantly reduce the efficiency of the installation and in extreme cases, can lead to a complete stop of installation.
\end{abstract}

\section{Introduction}

In 2018, in Poland through media reports [1-3], speculations have started on the rise in electricity prices in 2019 , which according to various sources can range from 10 to $80 \%$. The Polish economy and in particular professional energy branch is based on coal. In 2015, $85 \%$ of electricity generated in Poland came from coal. Therefore, as a reason for the increase in electricity prices in Poland are the price increase in the global coal market, the increase in prices of $\mathrm{CO}_{2}$ emission allowances, and also the costs of buying certificates related to the obligation to support renewable energy sources.

The increase in electricity prices [4-6] will effect on every area of the economy as well as daily life, including industry and residential installations powered by electricity. In order to reduce the influence on daily life of electricity price increases, the Polish government is analyzing and considering introducing a system of subsidies for electricity bills.

*Corresponding author: maciek.knapik@gmail.com 
On the example of a heating installation, where the main circulation pump of the installation, powered by electricity, during the heating season (usually from September to April), works almost continuously in this time, which results in the amount of electricity collected from the network, it achieves significant amounts, and in the context of increased operating costs, it can have a significant influence on the design process of a given system.

On the amount of electricity collected from the network by the circulation pump has several factors such as: flow of the heating medium, resistance of the installation, size of the pump, efficiency and the working time of the device. The main factor that generates operational costs is the flow resistance, which depends on the type of pipes used in the project, their diameters, fittings and the flow resistance of the receivers.

The article presents an analysis of the selection of pipes for heating installations $[7,8]$ in the context of the expected price increases for electricity, taking into account possible complications (precipitation of limescale on the internal walls of pipes) created during the operation of a heating installation.

\section{Assumptions for the case analysis}

In order to analyze the selection of heating pipes in the context of the increase in electricity prices, should be adopted certain assumptions, which are presented in Table 1.

Table 1. The basic assumptions of the case study (study of Author).

\begin{tabular}{|c|c|c|}
\hline Assumptions & Numerical data & Units \\
\hline Installation power & 150 & $\mathrm{~kW}$ \\
\hline Temperature parameters of the heating medium & $80 / 60$ & ${ }^{0} \mathrm{C}$ \\
\hline Design flow & 6.6 & $\mathrm{~m}^{3} / \mathrm{h}$ \\
\hline The duration of the heating season & 200 & days \\
\hline Analyzed length of the installation (summary) & 400 & $\mathrm{~m}$ \\
\hline Cost of kWh before the increase electricity prices & 0,55 & $\mathrm{PLN}$ \\
\hline The assumed increase in electricity prices & 40 & $\%$ \\
\hline Cost of kWh after the increase electricity prices & 0.77 & $\mathrm{PLN}$ \\
\hline
\end{tabular}

According to the Polish standard [9], the designer of the heating installation in the selection of heating installation pipes should be guided by three criteria: the flow rate of the heating medium in the pipe, which should to be in the range from 0.1 to $1.0 \mathrm{~m} / \mathrm{s}$, linear pressure drops, no greater than $150 \mathrm{~Pa} / \mathrm{m}$ and also an economic issue. For the assumed heating power of $150 \mathrm{~kW}$, with the parameters $80 / 60^{\circ} \mathrm{C}$, the design flow is $6.6 \mathrm{~m}^{3} / \mathrm{h}$.

Copper and PP (polypropylene) pipes are characterized by the highest investment costs, but from other side, steel pipes are characterized by a lower coefficient of roughness, thanks to which these, copper and PP pipes have greater resistance to limescale deposits. Steel pipes are cheaper, but these pipes that have a greater roughness, which supports the deposition of limescale and reduce the inner diameter of the pipe. As a consequence of this process, during the heating installation operation, the pressure losses increases and it also increases the total costs of system operation. The results are summarized in Fig. 1. 


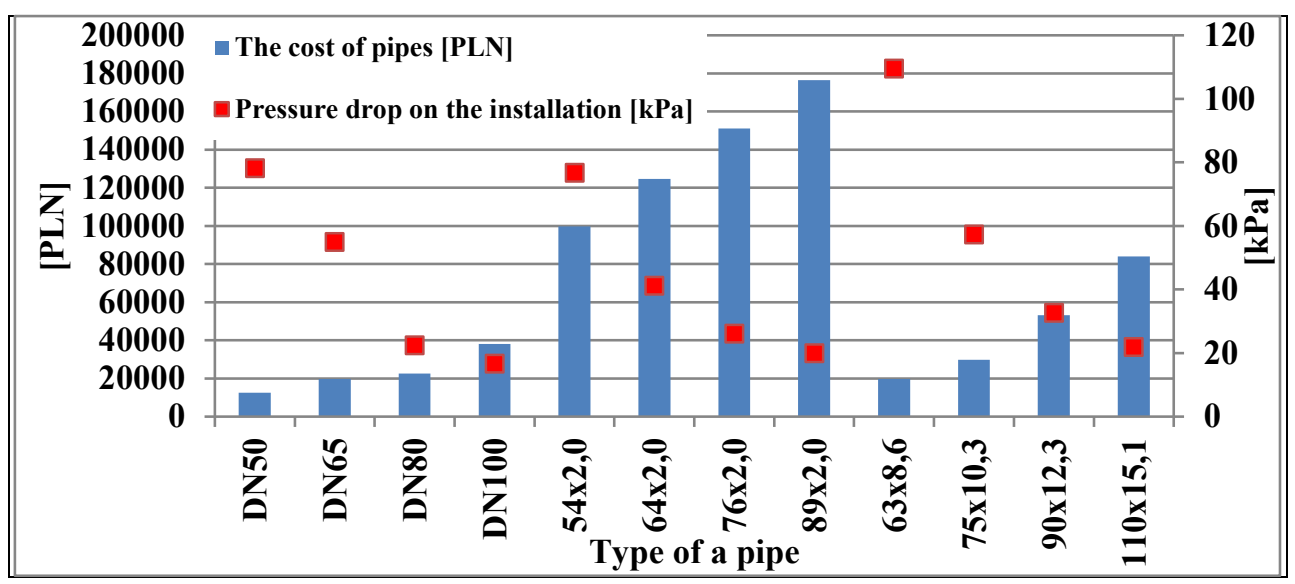

Fig. 1. Summary of investment costs with the total pressure drop of installation, designed on the type and diameter of the pipe (study of Author).

\section{Analysis of the pipe selection in the context of rising the electricity prices}

The operating costs of a heating installation depends on the type of the main circulation pump and the type of boiler room and used fuel $[10,11]$. The process of selecting the pump is based on the design flow of the heating medium and the pressure drops on the critical cycle. The higher values reach the indicated parameters, the higher amounts of the electric energy is needed to motive the pump and the size of the pump increases as well as the investment costs. Based on the initial assumptions from the Table 1 as the calculation flow of the heating medium of $6.6 \mathrm{~m}^{3} / \mathrm{h}$, and pressure drops on the system depending on the type of pipe used, several variants of pumps were selected, based on the Grundfos technical catalog [12] (for the time of operation the manufacturer gives a period of 15 years). The results are summarized in Fig. 2.

The obtained results of the selection of pumps and their nominal power (Fig. 3) coincide with the results of pressure drop in the installation (Fig. 1). The higher the pressure drop, the higher the pump power.

After taking into account an increases in electricity prices (Table 2), the type of selected pipe has not changed. It is still a steel pipe, but its diameter has changed.

In this case, the most profitable in economic terms, there has been a change to a pipe with two larger dimensions (DN80 steel pipe), where the total cost amounts 30880.22 PLN. The results are summarized in Fig. 3.

Fig. 3 presents the expected increase in the cost of operating a heating installation in the case of a $40 \%$ increase in electricity prices. The largest increases in costs were observed on an ex ample of smallest diameters of pipes of a given type.

The obtained results may be influenced by such factors as a constant increase in the costs of the energy, which was not taken into account in this analysis, as well as losses resulting from the duration of operation, of system like the precipitation of limescale on the inner wall surfaces of pipes. 


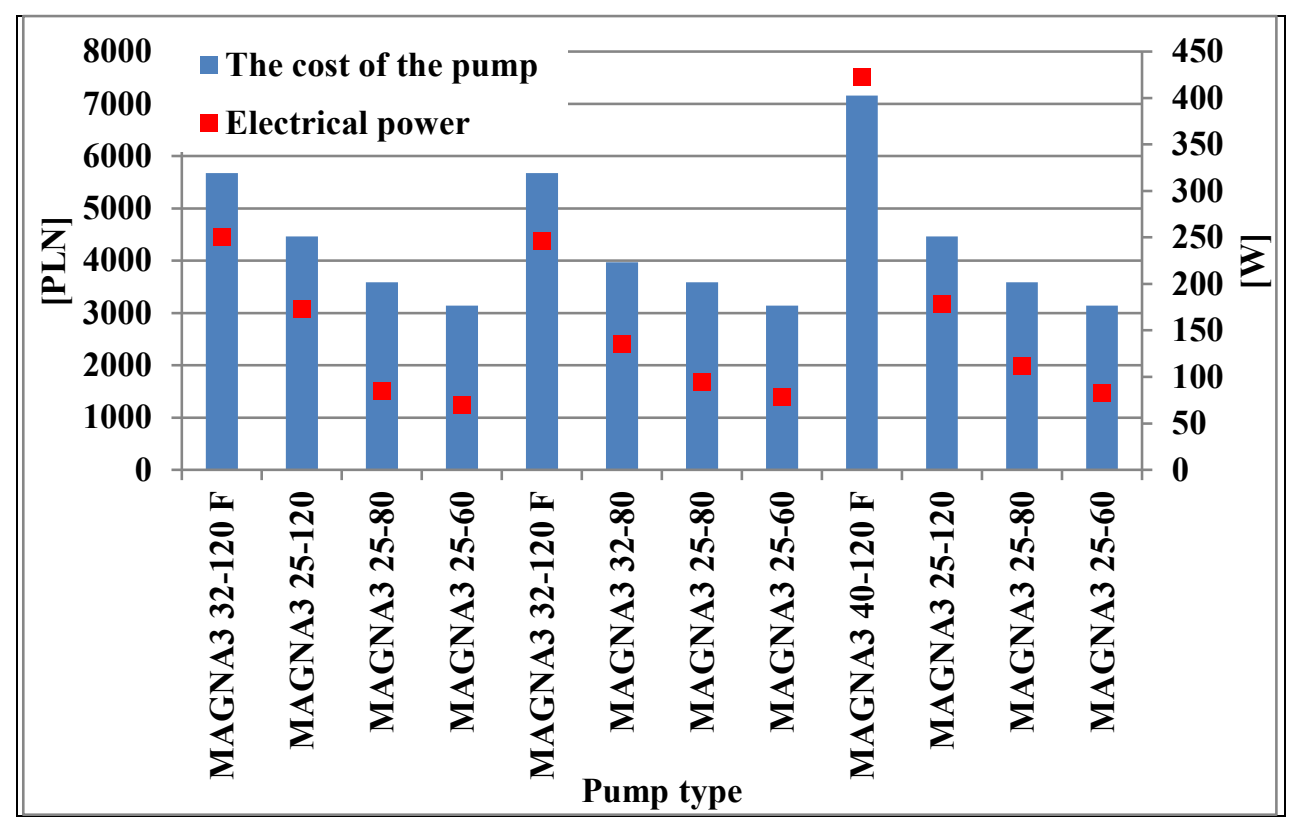

Fig. 2. Summary of the costs of the pump and the power of the device under nominal conditions (study of Author).

Table 2. Summary of the amount of energy consumed by pumps during the heating season, operating costs and total costs before and after the increase of electricity prices.

\begin{tabular}{|c|c|c|c|c|c|}
\hline Type of a pipe & $\begin{array}{c}\text { Electricity } \\
\text { consumption } \\
{[\mathbf{k W h}]}\end{array}$ & $\begin{array}{c}\text { Operating } \\
\text { costs I } \\
{[\text { PLN] }}\end{array}$ & $\begin{array}{c}\text { Operating } \\
\text { costs II } \\
{[\text { PLN] }}\end{array}$ & $\begin{array}{c}\text { Total } \\
\text { costs I } \\
{[\text { PLN] }}\end{array}$ & $\begin{array}{c}\text { Total } \\
\text { costs II } \\
{[\text { PLN] }}\end{array}$ \\
\hline Steel DN50 & 1204.8 & 9939.6 & 13915.44 & 28237.21 & 32213.05 \\
\hline Steel DN65 & 830.4 & 6850.8 & 9591.12 & 31068.78 & 33809.1 \\
\hline Steel DN80 & 408 & 3366 & 4712.4 & 29461.82 & 30808.22 \\
\hline Steel DN100 & 336 & 2772 & 3880.8 & 44122.77 & 45231.57 \\
\hline Copper 54x2.0 & 1180.8 & 9741.6 & 13638.24 & 115115.20 & 119011.9 \\
\hline Copper 64x2.0 & 648 & 5346 & 7484.4 & 134087.70 & 136226.1 \\
\hline Copper 76x2.0 & 456 & 3762 & 5266.8 & 158493.80 & 159998.6 \\
\hline Copper 89x2.0 & 374.4 & 3088.8 & 4324.32 & 182755.60 & 183991.1 \\
\hline PP 63x8.6 & 2030.4 & 16750.8 & 23451.12 & 43625.09 & 50325.41 \\
\hline PP 75x10.3 & 859.2 & 7088.4 & 9923.76 & 41438.38 & 44273.74 \\
\hline PP 90x12.3 & 537.6 & 4435.2 & 6209.28 & 61139.02 & 62913.1 \\
\hline PP 110x15.1 & 398.4 & 3286.8 & 4601.52 & 90349.57 & 91664.29 \\
\hline
\end{tabular}




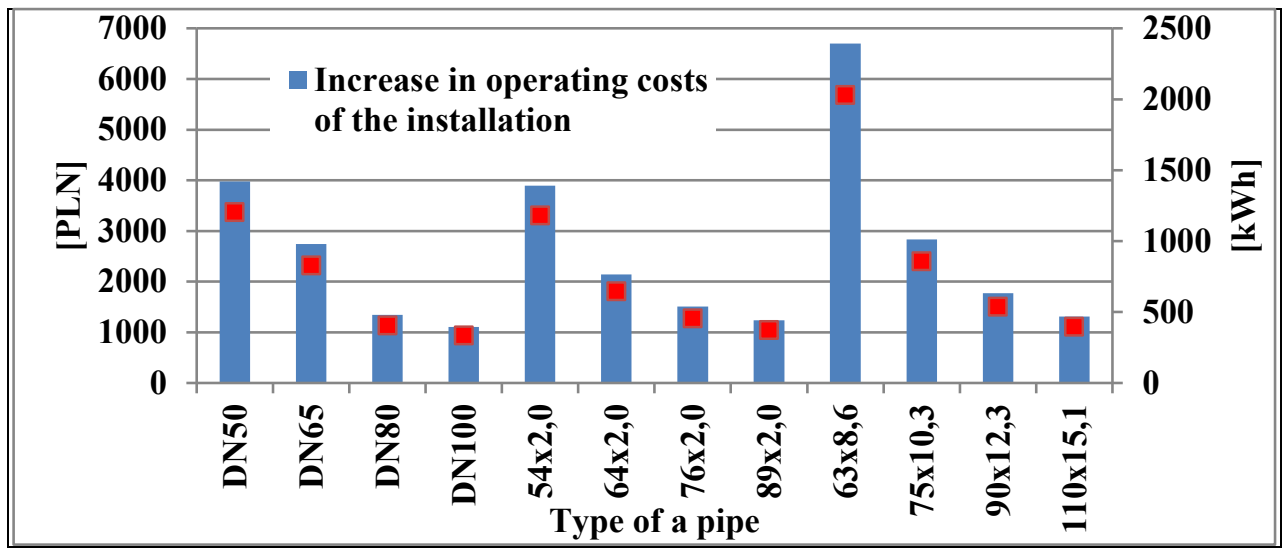

Fig. 3. Increase in operating costs of the heating installation in relation to the base state and the amount of energy consumed by the pump depending on the selected diameter and type of pipe (study of Author).

\section{Influence of limescale on the operation of pipes}

The steel pipes are characterized by the highest roughness factor in the scope of the analyzed pipes. Roughness is the mechanically perceptible surface irregularities resulting not due to its shape but the nature of their processing. The greater the roughness factor of the pipe, the greater it is their potential to precipitate on the inner wall surface of the pipe of the limescale. According to the principle of electrostatic interaction, particles that have already deposited on the inner wall surface, it will attract the next particles leading to sediment growth. The deposition of limescale decreases the inner diameter of the pipe, and consequently increases the pressure losses and operating costs of the heating installation.

The limescale $[13,14]$ is a layer of sediment of calcium carbonates $\left(\mathrm{CaCO}_{3}\right)$ and magnesium $\left(\mathrm{MgCO}_{3}\right)$, formed as a result of the thermal decomposition of calcium and magnesium bicarbonates contained in water, especially in hard water. As a result of the heating process, the bicarbonate ions $\mathrm{HCO}^{3-}$ to carbonate $\mathrm{CO}_{3}{ }^{2-}$ decompose. At the time of decomposition, the most difficult soluble carbonates then precipitate in the form of a precipitate (limescale) containing mainly $\mathrm{CaCO}_{3}$ (solubility $14 \mathrm{mg} / \mathrm{l}$ ) and $\mathrm{MgCO}_{3}$ (solubility $106 \mathrm{mg} / \mathrm{l}$ ) as shown by the reaction equation:

$$
\mathrm{Ca}\left(\mathrm{HCO}_{3}\right)_{2(a q)} \rightarrow \mathrm{CaCO}_{3(s)} \downarrow+\mathrm{H}_{2} \mathrm{O}_{(l)}+\mathrm{CO}_{2(g)} \uparrow
$$

The higher the hardness of water [10] (it is a water feature as a function of the concentration of calcium cations $\left(\mathrm{Ca}^{2+}\right)$ and magnesium $\left(\mathrm{Mg}^{2+}\right)$, and optionally iron (II) $\left(\mathrm{Fe}^{2+}\right)$ and manganese (II), $\left(\mathrm{Mn}^{2+}\right)$, and the higher the temperature parameters of the heating medium, the phenomenon of the precipitation of limescale becomes more intense.

Preventing the formation of limescale in water systems usually consists of the use of water softeners or demineralization, but not everywhere these treatments are used [15-18].

The growth of the limescale on the inner surface of the pipe reduces the internal diameter of the pipe by twice the thickness of this layer, so that the thickness of the scale layer of $1 \mathrm{~mm}$ will reduce the internal diameter of the pipe by a total of $2 \mathrm{~mm}$. Fig. 4 presents the results of changes in total and linear pressure drops depending on the thickness of the limescale layer in the analyzed steel pipes. 


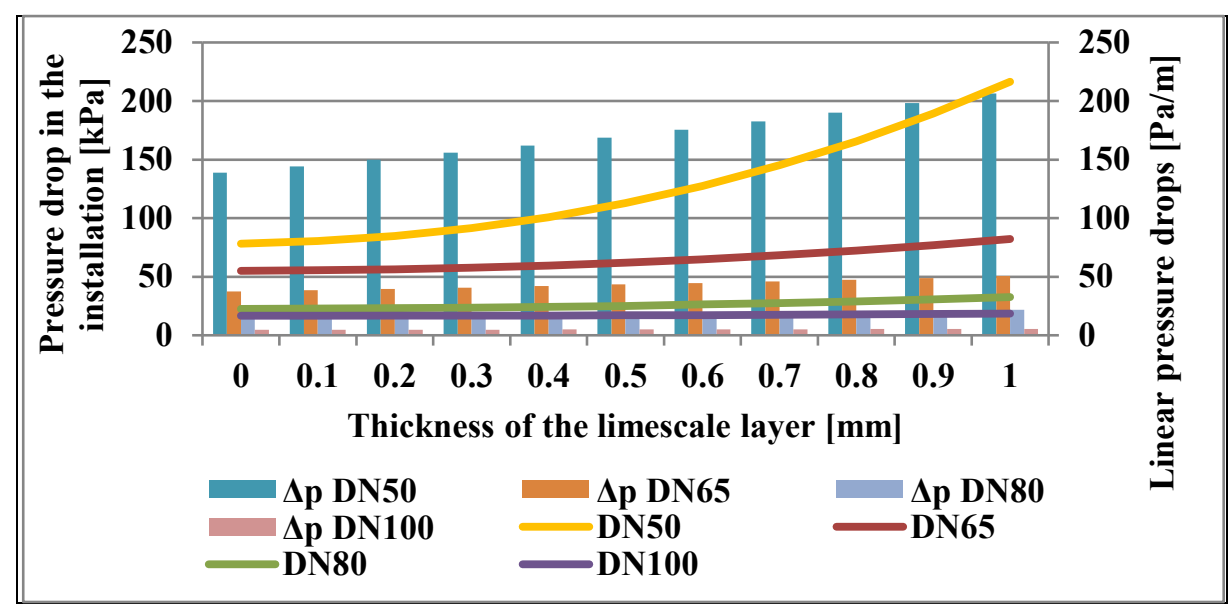

Fig. 4. The value of linear and total pressure drops of steel pipes depending on the thickness of the limescale in heating installation (study of Author).

In the case of a steel pipe with a diameter of DN50, thickness of the scale of $1 \mathrm{~mm}$, results in a reduction of inner pipe diameter by $2 \mathrm{~mm}$ and in consequence linear pressure drop are increased by almost $50 \%$. The effect of limescale growth on pressure drops in the analyzed installation is presented on Fig. 4.

The growth of the limescale will increase the operating costs of the heating installation, due to the increase in total pressure drops in the installation. In several cases, the installation will not work properly, because the selected pump (Fig. 2) is not able to meet the specified requirements (the flow can be increased at the expense of the pump pressure, however the nominal power of the heat receiver will be significantly reduced).

On Fig. 5 for diameters DN50 and DN65, for the limescale layer thickness of $0.5 \mathrm{~mm}$, for the MAGNA3 pumps, which were initially selected, the pressure drop exceeds the pump characteristic, which means a drop in efficiency, therefore the installation becomes ineffective, The nominal heat power of installation is reduced. In the case of the phenomenon of limescale deposition, the initial selection of the pipe, for economic reasons - the diameter of the DN50 steel pipe, during the operations turns out to be the wrong selection, the designer should be guided by a larger number of decision criteria. For diameters DN80 and DN100, differences in pump power values are minimal, therefore in further analysis only DN80 and DN100 steel pipes will be taken into consideration, because as mentioned above, for DN50 and DN65 diameters, pressure drops are too high, as a consequence of which the installation becomes ineffective.

Fig. 6 presents the results of operation costs of the installation based on DN80 and DN100 steel pipes and nominal power of the pump, taking into account the limescale deposits on the inner walls of the pipes. 


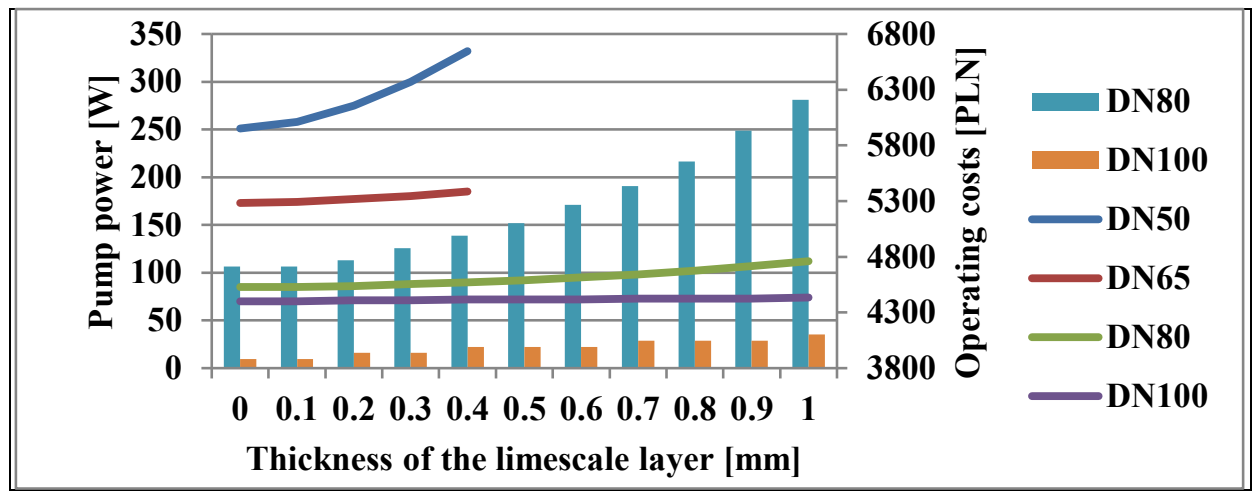

Fig. 5. The nominal power of the pump and operating costs of a heating installation designed on steel pipes depending on the thickness of the limescale (study of Author).

For a DN80 steel pipe, operating costs, over 15 years of operation of the heating installation, under influence of limescale, will increase by about $32 \%$, and in the case of a DN100 steel pipe costs will increase by about $6 \%$.

Taking into account all the analyzed aspects such as the increase in electricity prices and inclusion of limescale in steel pipes, obtained results of the analysis are presented on Fig. 6.

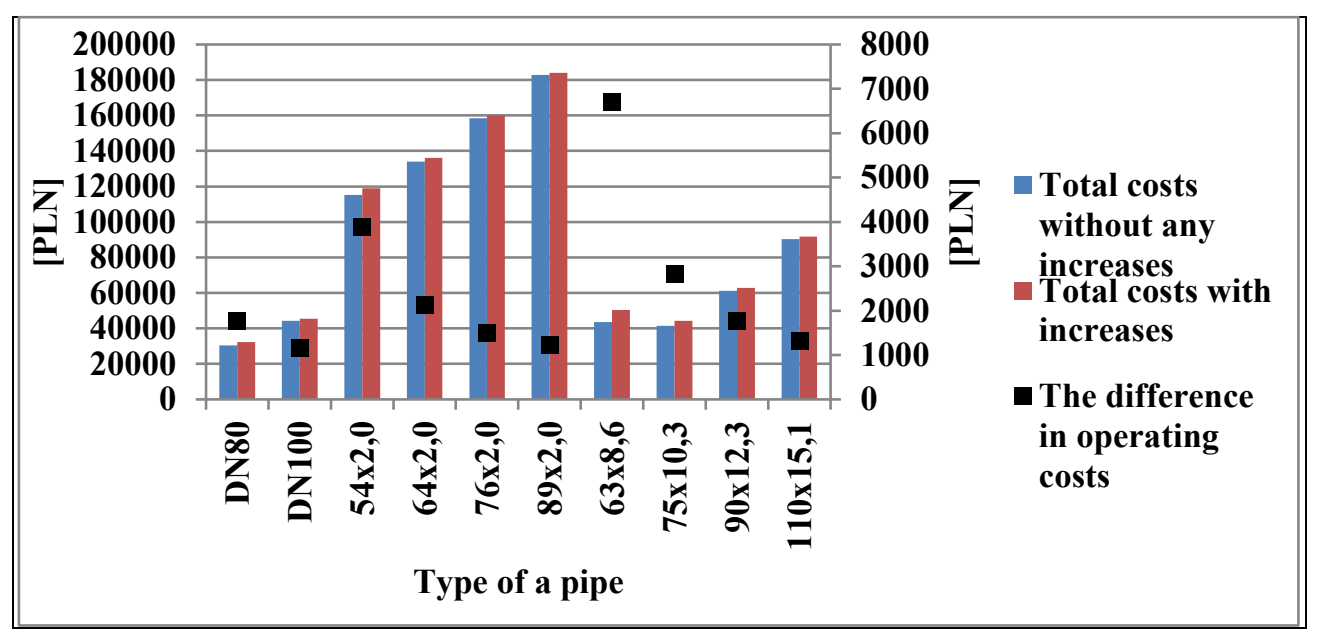

Fig. 6. Comparison of operating and total costs of heating installation before and after the prices increase for electricity (study of Author).

The DN50 and DN65 steel pipes were omitted, because taking into account the limescale, a new pump should be purchased or the pipes replaced to a new ones, which generates additional investment costs.

The smallest total costs, despite the expected price increases for electricity, are characterized by DN80 steel pipes, taking into account the formation of limescale, which amount depends on the water hardness. The largest total costs are characterized by copper pipes with a diameter of $89 \times 2.0$.

The smallest difference in operating costs before and after the increase in electricity charges was obtained for the DN100 steel pipes and the largest for PP pipes with a diameter of $63 \times 8.6$. 


\section{Summary and conclusions}

In connection with the planned increase in electricity costs, branch designers should take a broader look at the selection of pipes in the installation. As indicated by the analysis, not always following the guidelines indicated in the standard [9], leads to economically advantageous solutions. Lower investment costs do not always mean that the installation will be economically viable, by increasing operating costs.

On the example of the analysis of the selection of steel, copper and PP pipes, which allow to estimate that the price increase for electricity, which is used to motive a pump for heating installations, causes pipes that will be characterized by lower linear pressure drops over 15 years operation will be more economically (Fig. 6).

It should be known that the selection of pipes depends on the user with the support of the designer. Copper and PP pipes are more expensive (Fig. 1), but they have a lower coefficient of roughness, thanks to which they are more resistant to the formation of limescale on the surface of the inner walls of pipes. This phenomenon is more common in the analyzed steel pipes, which causes the reduction of the pipe inner diameter and as consequence it will increase installation pressure drops and the increase in operating costs of the system (Fig. 5). In extreme cases it will reduce nominal power of installation or it will completely stop the installation.

On the example of this analysis for installations characterized by a flow of $6.6 \mathrm{~m}^{3} / \mathrm{h}$ $(150 \mathrm{~kW})$, for a $400 \mathrm{~m}$ pipe (sum of supply and return), the increase in electricity costs increases the operating costs of the system over 15 years from around 1200 PLN up to 6700 PLN, depending on the type of selected pipe (Fig. 6).

The influence of limescale on the operation of the installation is presented on the background of steel pipes. The precipitation of a $1 \mathrm{~mm}$ thick layer of limescale reduces the pipe inner diameter by $2 \mathrm{~mm}$. Such a state of affairs based on the example of DN50 and DN65 steel pipes shows that the installation does not meet its requirements, works inadequately, inefficiently and uneconomically (Fig. 5).

For steel pipes DN80 and DN100, the precipitation of the limescale will accordingly increase the pressure loss on the system by $32 \%$ and $6 \%$ (Fig. 5).

The current trend in construction and installation branches is to reduce the energy demand of buildings by receiving eco-friendly certificates, obtaining passive house standards or low energy demand [19-25]. Therefore, the situation related to the anticipated increase in electricity prices is a good moment to verify project guidelines aimed at finding optimal solutions that ensure proper system operation, while maintaining the economic criterion during the operation of a given system and as well as reducing energy demand.

\section{References}

1. Ceny prądu w 2019 r. Jak duże podwyżki cen energii elektrycznej czekają nas w przyszłym roku? [online], Available at: https://gazetalubuska.pl/ceny-pradu-w-2019r-jak-duze-podwyzki-cen-energii-elektrycznej-czekaja-nas-w-przyszlymroku/ar/13596866, (Accessed: 30th January 2019)

2. Ceny prądu 2019. Podwyżki cen prądu w 2019 roku. Ile zapłacimy za prąd w 2019? [online], Available at: https://polskatimes.pl/ceny-pradu-2019-podwyzki-cen-pradu-w2019-roku-ile-zaplacimy-za-prad-w-2019/ar/13721250, (Accessed: 30th January 2019)

3. Ceny prądu w 2019 w roku - będą podwyżki? [online], Available at: https://enerad.pl/aktualnosci/ceny-pradu-2019/, (Accessed: 30 ${ }^{\text {th }}$ January 2019)

4. J. Liang Zhang, Y. Jun Zhang, D. Zhi Li, Z. Fu Tan, J. Fei Ji, Int. J. Elec. Power 105, 541-548 (2019) 
5. G. Müller, A. Seibert, Energy Econ. 78, 267-277 (2019)

6. H. Shavandi, M. Pirnia, J. D. Fuller, Appl. Energ, 240, 251-264 (2019)

7. O. Ibrahim, F. Fardoun, R. Younes, H. Louahlia-Gualousc, Build Environ. 72, 259-286 (2014)

8. K. C. Kavvadias, A. P. Tosios, Z. B. Maroulis, Energy Convers. Manag. 51, 833-845 (2010)

9. Polish standard, PN-EN 12:831 - 2006: Instalacje ogrzewcze w budynkach - Metoda obliczania projektowego obciażenia cieplnego

10. G. Martinopoulos, K. T. Papakostas, A. M. Papadopoulos, Energ. Buildings 124, 79-87 (2016)

11. M. Knapik, RI 9, 36-38 (2016)

12. Grundfos $\mid$ The full range supplier of pumps and pump solutions. [onlnie], Available at: https://www.grundfos.com/, (Accessed: $30^{\text {th }}$ January 2019)

13. Kamień kotłowy - Wikipedia, wolna encyklopedia [online], Available at: https://pl.wikipedia.org/wiki/Kamień kotłowy, (Accessed: $30^{\text {th }}$ January 2019)

14. D. Dobersek, D. Goricanec, Math. Models Methods Appl. Sci. 1, 55-61 (2007)

15. Twardość wody. [online], Available at: https://pl.wikipedia.org/wiki/Twardość_wody, (Accessed: $30^{\text {th }}$ January 2019)

16. K. Konieczny, S. Tanżyna, J. Marjanowski, M. Kosorz, Instal 12, 18-21 (2006)

17. J. Listewnik, O. Bezioukov, A. Nowik, Ultradźwiękowa metoda walki z tworzeniem się kamienia kotłowego lub innych osadów w urzadzeniach cieplno-energetycznych (Prace Naukowe Instytutu Techniki Cieplnej i Mechaniki Płynów Politechniki Wrocławskiej, Konferencje, 10, 120-127, 2000)

18. M. Mulik, M. Bożym, RI 5, 84-88 (2017)

19. M. Knapik, E3S Web Conf. 17, 00039 (2017)

20. M. Knapik, Budownictwo proekologiczne - zrównoważony rozwój (I Ogólnopolska Konferencja Naukowa OSA - Odpady, Środowisko, Atmosfera, 5-6 czerwca 2014, materiały pokonferencyjne, 87-92, 2014)

21. M. Knapik, Czas. Techn. 9, 137-150 (2017)

22. M. Knapik, E3S Web Conf. 44, 00069 (2018)

23. M. Knapik, RI 11, 22-30 (2017)

24. C. Thormark, Build. Environ. 37, 429-435 (2002)

25. I. Sartori, G. Hestnes, Energ. Buildings 39, 249-257 (2007) 